\title{
GRANICE OCHRONY TAJEMNICY DZIENNIKARSKIEJ W PROCESIE KARNYM
}

W demokratycznym państwie prawnym potrzeba ochrony tajemnicy dziennikarskiej spotyka się $\mathrm{z}$ powszechną niemal aprobata, jako inherentna konsekwencja afirmacji społecznej roli pełnionej przez przedstawicieli prasy oraz doniosłości funkcji przypisywanych środkom masowego komunikowania. W rezultacie na ustawodawcy i organach stosujących prawo ciąży obowiązek zadekretowania i wdrażania tej ochrony w ramach rzeczywistości społecznej i prawnej w sposób proporcjonalny do rangi i znaczenia tajemnicy dziennikarskiej. Stanowiąca kontrapunkt tej dążności konieczność zakreślenia prawnych ram poszanowania tego szczególnego sekretu jest zadaniem w równej mierze istotnym, a może nawet trudniejszym $\mathrm{w}$ aspekcie wiążącej się $\mathrm{z}$ nim odpowiedzialności. Wymaga bowiem uwzględnienia dalece złożonego w tym wypadku kontekstu aksjologicznego, a następnie przyjęcia takich rozwiązań, które będą przejawem należytego zrównoważenia potrzeby poszanowania tajemnicy dziennikarskiej oraz respektowania innych dóbr i wartości.

Już sama otoczka aksjologiczna tajemnicy dziennikarskiej nie odznacza się jednorodnością przedmiotu ochrony. Na tle tajemnicy adwokackiej, radcowskiej czy chociażby lekarskiej element ochrony interesu jednostkowego nie przesądza w sposób zasadniczy o społecznym sensie ustanowienia sekretu zawodowego. Nie ulega wątpliwości, że respektowanie tajemnicy dziennikarskiej ma na względzie dobro jednostek przekazujących dziennikarzowi określone informacje lub nawet innych osób, dobro doznające konkretyzacji w postaci okoliczności dotyczących życia prywatnego i rodzinnego człowieka, ale także jego działalności publicznej lub zawodowej ${ }^{1}$. Kierunek ochrony omawianej tajemnicy mocno wyznacza nadto konieczność zadośćuczynienia interesowi społecznemu. Innymi słowy, zachowanie w tajemnicy pewnych wiadomości odnoszących się zarówno do dziennikarza, jak i do osób przekazujących mu stosowne informacje może leżeć w interesie ogółu, przyczyniając się do podniesienia poziomu wiarygodności tego zawodu, sprzyjając rzetelności materiałów prasowych, utrwalając zaufanie społeczeństwa do prasy i umożliwiając mediom prawidłowe wykonywanie ich funkcji, a tym samym wzmacniając respektowanie wolności

\footnotetext{
${ }^{1} \mathrm{Na}$ tę dychotomię w aspekcie potrzeby ochrony zwracają również uwagę w odniesieniu do tajemnicy zawodowej w ogóle: B. Kunicka-Michalska, Ochrona tajemnicy zawodowej w polskim prawie karnym, Warszawa 1972, s. 17; M. Rusinek, Tajemnica zawodowa $i$ jej ochrona $w$ polskim procesie karnym, Warszawa 2007, s. 23.
} 
prasy $^{2}$, podniesionej w polskim porządku normatywnym do rangi podstawowej zasady ustrojowej Rzeczypospolitej (art. 14 Konstytucji). Wprawdzie związki zachodzące pomiędzy tajemnicą dziennikarską a wolnością prasy niekoniecznie - jak widać - plasuja się na płaszczyźnie bezpośredniej, niemniej jednak bezsporne jest, że poszanowanie pierwszego $\mathrm{z}$ wymienionych dóbr służy stworzeniu odpowiednich warunków do urzeczywistnienia drugiego, czyli oddziałując w pewnym, wycinkowym zakresie i w dalekosiężnej perspektywie na ukształtowanie takiego modelu organizacji życia społecznego, który w należytym stopniu hołduje zasadzie wolności prasy. I choć można się spierać, czy $\mathrm{w}$ ramach tak zarysowanej interferencji interesów chronionych tajemnica dziennikarską ten dotyczący dobra indywidualnego zostaje zawsze zdominowany przez dobro ogólne ${ }^{3}$, nie budzi wątpliwości fakt dualistycznego rozwarstwienia stosownej ochrony.

Z wielowymiarowa podstawa aksjologiczna tajemnicy dziennikarskiej logicznie skorelowany jest jej aspekt podmiotowy i przedmiotowy. W obu wypadkach zakres ochrony słusznie jawi się jako szeroki ${ }^{4}$ i stanowi odzwierciedlenie założeń systemowych przyjętych w odniesieniu do rozważanej tajemnicy. Zakres podmiotowy obejmuje bowiem nie tylko dziennikarza czy redaktora naczelnego poinformowanego o sprawach związanych z tą tajemnicą, lecz również inne osoby zatrudnione $\mathrm{w}$ redakcjach, wydawnictwach prasowych i innych jednostkach organizacyjnych tego typu (art. 15 ust. 3 , art. 16 ust. 3 p.p. ${ }^{5}$ ). $\mathrm{Z}$ kolei w myśl art. 15 ust. 2 p.p., w zakresie przedmiotowym zawierają się trzy kategorie wiadomości: 1) dane umożliwiające identyfikację autora materiału prasowego, listu do redakcji lub innego materiału o tym charakterze, 2) dane umożliwiające identyfikację innych osób udzielających informacji opublikowanych lub przekazanych do opublikowania, gdy te osoby zastrzegły sobie nieujawnianie danych tego rodzaju, 3) wszelkie informacje, których ujawnienie mogłoby naruszać interesy osób trzecich chronione prawem.

Tak ujęty standard ochrony tajemnicy dziennikarskiej rzutuje na cały porządek prawny, a zatem lege non distinguente odnosi się także do procesu

\footnotetext{
${ }^{2}$ Co bardzo silnie akcentują doktryna, Sąd Najwyższy oraz Europejski Trybunał Praw Człowieka; na ten temat zob. np. Z. Gostyński, Tajemnica dziennikarska a obowiazek sktadania zeznań $w$ procesie karnym, Warszawa 1997, s. 75-76; idem, Tajemnica dziennikarska a obowiazek sktadania zeznań $w$ nowym kodeksie postepowania karnego, „Państwo i Prawo” 1997, z. 10, s. 18; H. Gajewska-Kraczkowska, Tajemnica zawodowa dziennikarza a art. 163 k.p.k., „Państwo i Prawo” 1988, z. 6, s. 79; B. Michalski, Podstawowe problemy prawa prasowego, Warszawa 1998, s. 28 i 29; J. Sobczak, Tajemnica dziennikarska. Zakres, rola gwarancyjna, zakazy dowodowe - aspekty procesowe $i$ skutki $w$ zakresie prawa karnego materialnego, w: Z. Ćwiąkalski, G. Artymiak (red.), Wspótzależność prawa karnego materialnego $i$ procesowego $w$ świetle kodyfikacji karnych $z 1997 \mathrm{r}$. $i$ propozycji ich zmian, Warszawa 2009, s. 387-390; E. Ferenc-Szydełko, Prawo prasowe. Komentarz, Warszawa 2010, s. 139; A. Bojańczyk, Karnoprocesowe znaczenie zgody dziennikarza na sktadanie zeznań co do okoliczności objętych tajemnica zawodowa (wokót postanowienia Sadu Najwyższego z 15 grudnia 2004 r.), „Palestra” 2005, nr 9-10, s. 35; a także SN w uchwale z 19 stycznia 1995 r., I KZP 15/94, OSNKW 1995, nr 1-2, poz. 1, oraz Z. Gostyński, Glosa do wskazanej uchwały, „Państwo i Prawo” 1996, z. 1, s. 109.

${ }^{3}$ Tak przyjmuje, chyba na zasadzie nieuzasadnionej generalizacji, M. Rusinek, op. cit., s. 159-160.

${ }^{4}$ Analogicznie J. Sobczak, Prawo prasowe, Warszawa 2000, s. 314-315.

${ }^{5}$ Ustawa z 26 stycznia 1984 r. - Prawo prasowe, Dz. U. 1984, Nr 5, poz. 24 z późn. zm. (dalej jako: p.p.).
} 
karnego. Generalna okoliczność wiążąca się z prowadzeniem przez odpowiednie organy państwowe postępowań karnych implikuje jednakowoż konieczność rozważenia modyfikacji ogólnego zakresu ochrony wspomnianej tajemnicy, gdyż przywrócenie ładu społecznego naruszonego w wyniku popełnionego przestępstwa powinno nastąpić poprzez wydanie prawidłowego rozstrzygnięcia w przedmiocie kwestii odpowiedzialności karnej oskarżonego, a osiągnięcie tego celu może niekiedy usprawiedliwiać poświęcenie dóbr i wartości chronionych tajemnicą dziennikarską. Ta sytuacja, z natury rzeczy mocno kolizyjna, stanowi asumpt do poszukiwania rozwiązania iście kompromisowego, będącego konsekwencją właściwego zbilansowania zbiegających się dóbr. Trudno bowiem zadowolić się wypowiedzianym $\mathrm{w}$ doktrynie stwierdzeniem, iż dobro wymiaru sprawiedliwości odznacza się na ogół wyższym stopniem ważności niż zachowanie tajemnicy zawodowej ${ }^{6}$. W wypadku tajemnicy dziennikarskiej trafność tego zapatrywania załamuje się nie tylko z uwagi na akcentowane już wyżej jej olbrzymie znaczenie społeczne, lecz także ze względu na systemową niecelowość przyznawania pewnym wartościom generalnego prymatu nad innymi dobrami w wyniku przeprowadzenia niezwykle ogólnej, mglistej wręcz analizy oderwanej od konkretnych uwarunkowań prawno-społecznych. Oznacza to, że in concreto do wyobrażenia jest zarówno sytuacja, kiedy przewagę uzyska potrzeba ochrony tajemnicy dziennikarskiej, jak i wypadek, w którym zakres jej poszanowania ulegnie uszczupleniu na rzecz interesu wymiaru sprawiedliwości. Aby jednak możliwe było oszacowanie kolidujących ze sobą wartości w praktyce działania organów karnoprocesowych, ustawodawca musi stworzyć odpowiednią ku temu podstawę będącą dowodem zakresu preferowanej kompromisowości i akceptowanych przezeń założeń aksjologicznych.

Pierwszy wypadek, w którym dziennikarz jest zwolniony z zachowania tajemnicy, zaistnieje $\mathrm{w}$ razie pojawienia się konieczności egzekwowania prawnego obowiązku denuncjacji. Stylizacja odpowiednich przepisów Prawa prasowego (art. 16 ust. 1) oraz Kodeksu postępowania karnego (art. 180 § 4) sugeruje, że dziennikarz nie został wyłączony z grupy podmiotów przestępstwa ujętego w art. $240 \S 1$ k.k., polegającego na niezawiadomieniu organu ścigania o przygotowaniu, usiłowaniu lub dokonaniu czynu zabronionego należącego do zbioru najpoważniejszych przestępstw wyszczególnionych w tym przepisie ${ }^{7}$. $\mathrm{W}$ istocie trudno temu uregulowaniu odmówić racji, skoro zmniejszony jest

${ }^{6}$ Tak A. Ważny, Problemy zwolnienia z tajemnicy adwokackiej, dziennikarskiej i lekarskiej $w$ procesie karnym, „Prokuratura i Prawo” 1998, nr 10, s. 113. Por. prowadzone w innym kontekście wywody K. Marszała, dotyczące ważenia dóbr ze względu na kolizje interesów społecznych, w związku z instytucją zakazów dowodowych, w: idem (red.), S. Stachowiak, K. Zgryzek, Proces karny, Katowice 2005, s. $240-241$.

7 Tak również np. M. Szewczyk, w: A. Zoll (red.), Kodeks karny. Część szczególna. Komentarz do art. 117-277 Kodeksu karnego, Kraków 1999, s. 831; B. Kunicka-Michalska, Przestepstwa przeciwko ochronie informacji i wymiarowi sprawiedliwości. Rozdziat XXX i XXXIII Kodeksu karnego. Komentarz, Warszawa 2000, s. 140-141; A. Marek, Kodeks karny. Komentarz, Warszawa 2006, s. 443; J. Sobczak, Prawo prasowe. Komentarz, Warszawa 2008, s. 639-640. Zob. wywody doktryny poświęcone zawiłościom interpretacyjnym art. 16 ust. 1 p.p., np. Z. Gostyński, Glosa ..., s. 107-108; M. Rusinek, op. cit., s. 143-144; J. Sobczak, Tajemnica..., s. 408; A. Guzik, Prawnokarne aspekty ochrony tajemnicy dziennikarskiej, „Czasopismo Prawa Karnego i Nauk Penalnych” 2000, nr 1, s. 188-189. 
zakres ochrony tajemnicy dziennikarskiej na podstawie Kodeksu postępowania karnego w sytuacji, w której w grę wchodza przestępstwa godzące w podstawowe dobra jednostki lub naczelne i nadrzędne interesy państwa i całej społeczności (na ten temat - w dalszej części opracowania). W racjonalnym związku z tą trafną regulacją musi pozostawać nałożenie na dziennikarza obowiązku zawiadomienia o czynie zabronionym tego rodzaju. Należy wszak mocno zaakcentować, że zobowiązanie dziennikarza wyczerpuje się wyłącznie $\mathrm{w}$ dokonaniu stosownego powiadomienia, natomiast nie rozciąga się na etap przesłuchania $\mathrm{w}$ procesie karnym w charakterze świadka co do okoliczności objętych tajemnica zawodowa - w tym zakresie dziennikarz podlega odrębnemu unormowaniu zawartemu $\mathrm{w}$ art. $180 \S 2-4$ k.p.k.

Ocena tego unormowania, zwłaszcza w części dotyczącej ogólnej podstawy zwalniania dziennikarza $\mathrm{z}$ zachowania tajemnicy na użytek realizowania obowiązku świadczenia (art. $180 § 2$ k.p.k.), nie może być już tak jednoznaczna. Wprawdzie z uznaniem należy powitać wyposażenie jedynie sądu $\mathrm{w}$ kompetencję do podejmowania odpowiedniej w tym względzie decyzji, także na etapie postępowania przygotowawczego, ale pojawiają się istotne zastrzeżenia w odniesieniu do ustawowych warunków mających przesądzać o możliwości zeznawania dziennikarza $\mathrm{w}$ charakterze świadka co do okoliczności objętych tajemnicą. W takiej roli występują dwie przesłanki: niezbędność przesłuchania dla dobra wymiaru sprawiedliwości oraz niemożność ustalenia danej okoliczności na podstawie innego dowodu.

W literaturze przedmiotu zauważalny jest brak jednomyślności w kwestii oceny omawianego uregulowania. Dostrzec więc można ostrożną aprobatę opartą na twierdzeniu dotyczącym zobiektywizowania wymienionych kryteriów poprzez przyjęcie konieczności realizacji w tej sytuacji zasady prawdy i zapewnienia prawidłowego wyrokowania, gdy brak innych dowodów $\mathrm{z}$ powodu wyczerpania się możliwości dowodowych ${ }^{8}$. Zauważalna jest także dość powściągliwa kontestacja prowadząca do konkluzji podkreślającej identyczny de facto zakres znaczeniowy obu przesłanek i postulującej zastapienie obu warunków jednym, nieco ściślejszym ${ }^{9}$. Nadto, formułuje się dalej idące poglądy krytyczne proponujące albo dodanie nowego, trzeciego warunku polegającego na uwzględnieniu ważnego interesu prywatnego niesprzecznego $\mathrm{z}$ celami wymiaru sprawiedliwości ${ }^{10}$, albo uczynienie $\mathrm{z}$ tajemnicy dziennikarskiej

8 Z. Gostyński, Tajemnica dziennikarska a obowiazek sktadania zeznań $w$ procesie..., s. 114 i 116-117; idem, Tajemnica dziennikarska a obowiazek sktadania zeznań w nowym kodeksie..., s. 13 i 22; R. A. Stefański, Ujawnienie tajemnicy zawodowej przez świadka $w$ nowym kodeksie postępowania karnego, „Prokuratura i Prawo” 1998, nr 4, s. 123; A. Ważny, op. cit., s. 120.

9 Tak M. Rusinek, op. cit., s. 152-154.

${ }^{10}$ Przy okazji analizowania tajemnicy zawodowej w ogóle lub innych sekretów chronionych normą z art. $180 \S 2$ k.p.k., zob. P. K. Sowiński, Prawo świadka do odmowy zeznań w procesie karnym, Warszawa 2004, s. 210-217; idem, Zwolnienie adwokata z obowiazku zachowania tajemnicy zawodowej $w$ procesie karnym, „Monitor Prawniczy” 2004, nr 3, s. 111-112; por. także idem, Glosa do wyroku Trybunatu Konstytucyjnego z dnia 22 listopada 2004 r., sygn. SK 64/03, „Prokuratura i Prawo” 2007, nr 4, s. 176-178; idem, Gwarancje ochrony praw świadka w polskim procesie karnym. Zarys problematyki, w: E. Dynia, C. P. Kłak (red.), Europejskie standardy ochrony praw człowieka a ustawodawstwo polskie, Rzeszów 2005, s. 348. 
bezwzględnego zakazu dowodowego możliwego do przełamania tylko w wypadkach dotyczących przestępstw objętych z mocy art. 240 k.k. prawnym obowiązkiem doniesienia ${ }^{11}$.

Odnosząc się wpierw do przytoczonych poglądów opartych na najbardziej krytycznej analizie rozpatrywanego przepisu, należy odrzucić propozycję uzupełnienia zamieszczonej w nim regulacji o warunek uwzględnienia ważnego interesu prywatnego niesprzecznego z celami wymiaru sprawiedliwości, gdyż antynomia między oboma interesami zazwyczaj będzie właśnie zachodzić ${ }^{12}$. Atrakcyjnie przedstawia się koncepcja poszerzenia zakresu ochrony tajemnicy dziennikarskiej w wyniku dopuszczenia do jej uchylenia jedynie wtedy, gdy przedmiotem postępowania jest przestępstwo o wysokim ciężarze gatunkowym objęte obowiązkiem denuncjacji. Przyjęcie tego zapatrywania mogłoby jednak oznaczać odgórne wykluczenie możliwości dowodowego wykorzystania w procesie karnym zeznań dziennikarza co do okoliczności zamykających się w jego tajemnicy, i to w odniesieniu do zdecydowanej większości przestępstw, a zatem byłoby równoznaczne $\mathrm{z}$ niebezpiecznym chyba przesunięciem punktu równowagi w stronę ochrony tej tajemnicy w warunkach wystąpienia niemożliwego do zaaprobowania bardzo prawdopodobnego uszczerbku dla dobra wymiaru sprawiedliwości. Można więc wyobrazić sobie na tle tego rozwiązania respektowanie interesów niekoniecznie zasługujących na ochronę ${ }^{13}$.

$\mathrm{Z}$ drugiej strony nawet daleka od wnikliwości analiza wskazanych wyżej warunków nie skłania do szczególnego optymizmu w zakresie eksploracji wyważonego kompromisu. Powstaje bowiem pytanie, czy delimitacja ochrony tajemnicy dziennikarskiej może być konsekwencją wprowadzenia do tekstu ustawy sformułowań dalece ogólnikowych lub zbyt niedookreślonych. Nie sposób oprzeć się wrażeniu, że kategoria „niezbędności dla dobra wymiaru sprawiedliwości”, o której mowa w art. 180 § 2 k.p.k., wydaje się zbędna, $\mathrm{w}$ każdym bowiem pojedynczym procesie karnym należy $\mathrm{w}$ imię zadośćuczynienia temu dobru zmierzać do wyjaśnienia okoliczności sprawy w zakresie umożliwiającym wydanie prawidłowego rozstrzygnięcia ${ }^{14}$. Można nawet zaryzykować twierdzenie, że zamieszczenie takiej klauzuli w analizowanym przepisie, ze względu na jej niekwestionowaną ogólnikowość, ma tylko ułatwić sądowi wydanie decyzji pozytywnej. Z kolei drugi z wymienionych wcześniej warunków zmusza sąd do weryfikacji materiału dowodowego w danej sprawie, ale weryfikacji obarczonej istotnym ryzykiem trudności, gdyż zakończonej

11 Tak w odniesieniu do tajemnicy adwokackiej A. Murzynowski, Refleksje na tle Uchwaty Naczelnej Rady Adwokackiej dotyczacej tajemnicy adwokackiej, „Palestra” 1994, nr 11, s. 57; ściśle w stosunku do tajemnicy dziennikarskiej S. Waltoś, Prawo do tajemnicy dziennikarskiej a dowód prawdy na tle europejskich standardów ochrony praw człowieka, „Państwo i Prawo” 1996, z. 4-5, s. 143; oraz w ogólności względem tajemnic zawodowych z art. 180 § 2 k.p.k. - L. K. Paprzycki, w: J. Grajewski, L. K. Paprzycki, M. Płachta, Kodeks postepowania karnego. Komentarz do art. 1-424 k.p.k., t. I, Kraków 2003, s. 446-447.

${ }^{12}$ Na co zwrócił także uwagę M. Rusinek, op. cit., s. 150-151.

${ }^{13}$ Por. Z. Doda, A. Gaberle, Dowody $w$ procesie karnym. Orzecznictwo Sadu Najwyższego. Komentarz, t. I, Warszawa 1995, s. 237; J. Sobczak, Tajemnica..., s. 412; M. Rusinek, op. cit., s. 151.

${ }^{14}$ Chociaż niekoniecznie owo rozstrzygnięcie musi być oparte na pełnej podstawie dowodowej, tak jak chce tego L. K. Paprzycki, w: J. Grajewski, L. K. Paprzycki, M. Płachta, op. cit., s. 446. 
wytworzeniem się (jakby sugerowała treść omawianego przepisu) stanu pewności co do wyczerpania środków dowodowych. Tymczasem w wielu tego typu wypadkach po stronie sądu zaistnieje co najwyżej stan przeświadczenia we wskazanej kwestii, zważywszy że sąd występuje w roli prognozującego, a zatem co prawda ocenia aktualną zawartość materiału dowodowego, ale niejednokrotnie $\mathrm{w}$ perspektywie możliwości jego uzupełnienia lub braku takiej możliwości w przyszłości.

Warto zauważyć, że ten sam art. 180 § 2 k.p.k. w analogicznym zakresie dotyczącym tajemnicy radcy prawnego był przedmiotem kontroli Trybunału Konstytucyjnego ${ }^{15}$, który trafnie nie dopatrzył się niekonstytucyjności tego przepisu z powodu zawartych w nim przesłanek, niemniej jednak niesłusznie uznał za nieuzasadniony zarzut ich niedookreśloności. Zdaniem Trybunału, o zwolnieniu decyduje sąd dysponujący już całym materiałem zebranym w postępowaniu przygotowawczym. Nie sposób podzielić optymizmu Trybunału w kwestii konkretności i sprawdzalności drugiej z omawianych przesłanek, chociażby z tego powodu, że przeszkodą może się okazać jednoznaczne ustalenie momentu czasowego determinującego ziszczenie się tej przesłanki, a - w świetle podniesionych wątpliwości wiążących się z brakiem większej precyzyjności obu warunków - nieuzasadniona pokusa sięgania po zeznania dziennikarza w zakresie chronionym tajemnicą zawodową może się ujawnić na różnych etapach postępowania przygotowawczego ${ }^{16}$.

Należałoby więc opowiedzieć się za wyeliminowaniem z treści art. 180 $\S 2$ k.p.k. warunku odwołującego się do dobra wymiaru sprawiedliwości i zarazem zastanowić się nad ewentualną rekonstrukcją stosownych przesłanek w stronę przyjęcia rozwiązania cechującego się większą precyzyjnością i wprowadzającego stan wyższej pewności prawnej w aspekcie sytuacji dziennikarza zobowiazanego do zachowania tajemnicy zawodowej, przy jednoczesnym zabezpieczeniu interesów związanych $\mathrm{z}$ wydaniem prawidłowego rozstrzygnięcia $\mathrm{w}$ kwestii przedmiotu procesu. Powstaje zasadne w kontekście dotychczasowych rozważań pytanie, czy ustanowienie rozwiązania odpowiadającego wskazanym kryteriom jest w ogóle możliwe. W każdym razie rzetelnie należy podkreślić, że wady uregulowania art. $180 \S 2$ k.p.k. w pewnym sensie niweluje fakt wyraźnego zaakcentowania w tym przepisie wyjątkowości sytuacji polegającej na przesłuchaniu dziennikarza co do okoliczności objętych jego tajemnicą ${ }^{17}$ oraz niecałkowity - co do zasady - charakter zwolnienia dziennikarza z obowiązku utrzymywania tego sekretu.

Zgodnie bowiem z art. 180 § 3 k.p.k., owo zwolnienie nie może dotyczyć dwóch kategorii danych składających się na treść tajemnicy dziennikarskiej, mianowicie wiadomości chronionych prawem do anonimatu i źródeł informacji dziennikarskiej. To ograniczenie nie obowiązuje natomiast (co oznacza, że zwolniony dziennikarz musi ujawnić wszelkie dane objęte tajemnicą), gdy

\footnotetext{
${ }^{15}$ Wyrok TK z 22 listopada 2004 r., sygn. SK 64/03.

${ }^{16}$ Zob. kierunek krytyki orzeczenia TK przyjęty przez P. K. Sowińskiego, Glosa..., s. 176-177. Zob. także L. K. Paprzycki, w: J. Grajewski, L. K. Paprzycki, M. Płachta, op. cit., s. 446-447.

${ }^{17}$ Co zauważyli także np. Z. Kwiatkowski, Zakazy dowodowe $w$ procesie karnym, Katowice 2001, s. 166, oraz R. A. Stefański, op. cit., s. 123.
} 
informacja dotyczy przestępstw, co do których przewidziano w art. $240 \S 1$ k.k. prawny obowiązek denuncjacji (art. $180 § 4$ k.p.k.). W świetle tak ukształtowanej regulacji ustawowej trudno raczej uznać zakaz dowodowy stanowiący tajemnicę dziennikarską za bezwzględny, nawet jeżeli pełne ujawnienie wiążących się $\mathrm{z}$ nią wszystkich potencjalnych informacji aktualizuje się w odniesieniu do nielicznej grupy przestępstw, i to tych charakteryzujących się najwyższym ciężarem gatunkowym ${ }^{18}$.

Najdalej idąca ochrona tajemnicy dziennikarskiej w odniesieniu do danych autora materiału prasowego lub informatora zasługuje zresztą na akceptację, przynajmniej w tej części, w której dotyczy dziennikarza przesłuchiwanego w charakterze świadka. Przedmiotem ochrony sa w tym wypadku wiadomości, które tworzą najbardziej wrażliwy aspekt tej tajemnicy $\mathrm{w}$ sensie niebezpieczeństwa wyrządzenia potencjalnych szkód i zarazem najdonioślejszy ze względu na społeczną pozycję i rolę prasy. Sa to informacje, których poszanowanie w bardzo wyrazisty sposób odzwierciedla potrzebę kształtowania społecznego zaufania do przedstawicieli mediów i nieskrępowanego wykonywania funkcji pełnionych przez środki przekazu. Rozwiązanie zasadzające się na konieczności rezygnacji przez przesłuchiwanego dziennikarza $\mathrm{z}$ anonimatu lub na niezbędności identyfikacji informatora tylko w sytuacjach wyjątkowych uzależnionych od jednoczesnego istnienia prawnego obowiązku doniesienia o najpoważniejszych przestępstwach jest w odpowiedni sposób wyważone i nie odbiega od założeń zasady proporcjonalności (art. 31 ust. 3 Konstytucji). $\mathrm{Z}$ wymienionych powodów nie można więc zaaprobować krytycznego poglądu wyrażonego w piśmiennictwie pod adresem regulacji art. 180 § 3 k.p.k. ${ }^{19}$

Pewne zastrzeżenia co do trafności ukrycia danych autora materiału prasowego pojawią się natomiast wtedy, gdy podda się analizie zupełnie inny układ faktyczno-procesowy związany z dokonaniem przestępstwa prasowego przez dziennikarza. Brak związków między tą sytuacją a obowiązkiem denuncjacji oraz dość rygorystyczne traktowanie w przepisach Prawa prasowego ochrony prawa do anonimatu powodują, że powstaną wówczas przeszkody w zidentyfikowaniu sprawcy przestępstwa, na przykład dziennikarza popełniającego w prasie zniesławienie. Bez określenia osoby oskarżonego nie sposób wnieść aktu oskarżenia ${ }^{20}$. Wydaje się, że niezależnie od tego, że istnieje

${ }^{18}$ Zbliżony wniosek: P. Hofmański (red.), E. Sadzik, K. Zgryzek, Kodeks postępowania karnego. Komentarz do artykutów 1-296, t. I, Warszawa 2004, s. 760-761. Twierdzenie o bezwzględnym charakterze zakazu statuowanego w art. $180 \S 3$ k.p.k. sprecyzował Sąd Najwyższy w uchwale z 22 listopada 2002 r., sygn. I KZP 26/02, OSNKW 2003, nr 1-2. Zob. glosę aprobującą do tego orzeczenia autorstwa A. Gereckiej-Żołyńskiej, OSP 2004, nr 1, s. 22-24; a także podobne w swej treści stanowiska: T. Grzegorczyk, Kodeks postepowania karnego. Komentarze Zakamycza wraz z komentarzem do ustawy o świadku koronnym, Kraków 2003, s. 473; A. Guzik, op. cit., s. 185; M. Rusinek, op. cit., s. 159.

19 Tak M. Rusinek, który opowiada się za uchyleniem $\S 3$ i 4 art. 180 k.p.k. i poddaniem tajemnicy dziennikarskiej w całości reżimowi art. 180 § 2 k.p.k. (idem, op. cit., s. 160-161). Postulowane przez wskazanego autora wzmacnianie zaufania obywateli do wymiaru sprawiedliwości trzeba realizować innymi sposobami i przy innych okazjach, a nie poprzez wprowadzanie rozwiązań uzależniających respektowanie interesu prasy oraz osób udzielających jej informacji od uznania sądu, i to w sposób niekoniecznie proporcjonalny do stopnia zakłócenia porządku publicznego w aspekcie wagi przestępstwa i skutków, jakie ten czyn wywołał.

${ }^{20}$ K. Marszał, w: idem (red.), S. Stachowiak, K. Zgryzek, op. cit., s. 246. 
możliwość skierowania oskarżenia przeciwko redaktorowi naczelnemu ponoszącemu odpowiedzialność karną $\mathrm{z}$ tytułu decyzji o publikacji (art. 25 ust. 4 p.p.), należałoby rozważyć próbę uregulowania w przepisach Prawa prasowego kwestii obowiązku ujawnienia danych autora materiału prasowego $\mathrm{w}$ celu zapewnienia skutecznego ścigania przestępstw popełnianych w środkach masowego komunikowania.

Oczywiście, tego typu wymóg byłby aktualny jedynie wtedy, gdyby nie doszło do uchylenia tajemnicy dziennikarskiej w sposób logiczny z punktu widzenia jej istoty. Chodzi mianowicie o możliwość jej wyłączenia w razie wyrażenia zgody przez autora materiału prasowego na ujawnienie jego nazwiska. To generalne zastrzeżenie wraz $\mathrm{z}$ identycznym dotyczącym zgody informatora (art. 16 ust. 1 p.p.) uzupełniają w każdym razie normatywny model ochrony omawianej tajemnicy. Potrzeba jej zagwarantowania w sposób przejrzysty i koherentny warunkujący stan jasności prawnej w kwestii granic jej respektowania wymusza konieczność zwrócenia uwagi na sytuację, która wiązałaby się z faktycznym uchyleniem sekretu dziennikarskiego i dokonania oceny tej sytuacji.

Rzecz tyczy się problemu samorzutnego zwolnienia się dziennikarza $\mathrm{z}$ obowiązku zachowania tajemnicy zawodowej - kwestia ta nie została wprost uregulowana $\mathrm{w}$ obowiązujących przepisach, ani w kierunku uznania dopuszczalności takiego zachowania, ani w stronę przyjęcia braku stosownej możliwości. Stała się natomiast przedmiotem zainteresowania Sądu Najwyższego, który w postanowieniu z 15 grudnia $2004 \mathrm{r}^{21}$ sformułował tezę aprobująca dopuszczalność samozwolnienia się dziennikarza. Analiza uzasadnienia tego orzeczenia prowadzi do wniosku, że Sąd Najwyższy skoncentrował swą uwagę na tym wypadku, w którym dziennikarz jest przesłuchiwany $\mathrm{w}$ charakterze świadka, natomiast nie odniósł się do sytuacji, w której dziennikarzowi przysługuje status oskarżonego, pomimo że stan faktyczny, na kanwie którego to postanowienie zapadło, obejmował obie sytuacje. Rozpatrywana kwestia jest dość skomplikowana i złożona, dlatego celowe jest odrębne jej omówienie $\mathrm{w}$ odniesieniu do każdego $\mathrm{z}$ wymienionych wypadków.

W pierwszej kolejności rozważany problem należy uczynić przedmiotem analizy, gdy dziennikarz występuje w roli świadka. Już na wstępie trzeba zauważyć, że stylizacja językowa art. 180 § 2 k.p.k., a zwłaszcza użycie zwrotu „osoby zobowiązane do zachowania tajemnicy [...] dziennikarskiej moga być przesłuchiwane co do faktów objętych tą tajemnica tylko wtedy [...]", zdaje się sugerować niedopuszczalność nie tylko odbycia przesłuchania w warunkach braku zwolnienia udzielonego przez sąd, ale i wtedy, gdy dziennikarz samodzielnie zdecydowałby zeznawać co do tych okoliczności, wyprzedzając zajęcie stanowiska $\mathrm{w}$ tym przedmiocie ze strony sądu ${ }^{22}$. Na tle tezy wypowiedzianej

${ }^{21}$ Sygn. III KK 278/04, OSNKW 2005, nr 3, poz. 28.

${ }^{22}$ Zob. argumentacje o charakterze gramatycznym i systemowym przyjęta przez: D. Szumiło-Kulczycka, Glosa do postanowienia Sadu Najwyższego z 15 XII 2004, III KK 278/04, „Państwo i Prawo” 2005, z. 12, s. 126-127; M. Rusinka, op. cit., s. 108-109 oraz D. Karczmarska, Prawnokarna ochrona tajemnicy a dowód z zeznań i wyjaśnień - zagadnienia wybrane, w: Z. Ćwiąkalski, G. Artymiak (red.), Wspótzależność prawa karnego materialnego i procesowego $w$ świetle kodyfikacji karnych $z 1997 \mathrm{r}$. i propozycji ich zmian, Warszawa 2009, s. 431-433. Generalnie przeciwko samorzutnemu zwalnianiu się 
przez Sąd Najwyższy trudno tym bardziej zakładać, stosując wykładnię logiczna i systemową, że dziennikarz jest uprawniony dokonać samozwolnienia w części dotyczącej ochrony anonimatu i danych informatorów.

Wskazaną argumentację można wzmocnić, odwołując się do innych okoliczności. Struktura tajemnicy o charakterze zawodowym sprowadza się do wyodrębnienia stosunku typu: dysponent-depozytariusz, odznaczającego się wyraźnym podziałem ról $\mathrm{w}$ aspekcie relacji do potrzeby nieujawniania informacji objętych tą tajemnicą. Obejmuje ona uprawnienie w wypadku dysponenta oraz obowiązek w odniesieniu do depozytariusza, co w ramach sekretu dziennikarskiego musi, rzecz jasna, oznaczać brak możliwości samowolnego „złamania” przez dziennikarza - jedynie depozytariusza zakazu objętego tą tajemnicą ${ }^{23}$. W ramach obrony słuszności tezy wyrażonej przez Sąd Najwyższy $\mathrm{w}$ literaturze podzielono zapatrywanie tego organu co do etycznego charakteru tajemnicy dziennikarskiej, a ponadto podniesiono, że za trafnością tej tezy przemawia brak zakazu dowodowego $\mathrm{w}$ zakresie przeprowadzenia dowodu $\mathrm{z}$ przesłuchania dziennikarza ujawniającego tę tajemnicę $\mathrm{z}$ własnej inicjatywy ${ }^{24}$. Twierdzenie o etycznym wymiarze omawianej tajemnicy nie brzmi zrozumiale, zważywszy na jej ewidentna podstawę prawna, a nawet jeśli przyjmować, że aktualizuje się ono $\mathrm{w}$ znaczeniu uzupełniającym regulację normatywną, to i tak nie niweluje zasadniczych wattpliwości pojawiających się na tle lektury wspomnianego orzeczenia Sądu Najwyższego. Gdyby bowiem akceptować zapatrywanie najwyższej instancji sądowej, że problem wyjawienia tajemnicy pozostawiony jest sumieniu dziennikarza, który - uznając to za słuszne - może nawet wskazać swego informatora, godzimy się na swobodne kształtowanie przez dziennikarza zakresu ochrony wiążącego go sekretu zawodowego, a w rezultacie na dość niebezpieczne i szkodliwe skutki tego stanu rzeczy łączące się $\mathrm{z}$ osłabieniem społecznego znaczenia tajemnicy dziennikarskiej oraz wypaczeniem jej istoty i sensu. Jak trafnie zaznacza się $\mathrm{w}$ piśmiennictwie ${ }^{25}$, niezwykle problematyczna jest $\mathrm{w}$ tym wypadku kwestia kryteriów uprawniających dziennikarza do dokonania samozwolnienia, będących w gruncie rzeczy dowolnymi, co oznaczałoby przyznanie temu podmiotowi możliwości zupełnie arbitralnego działania, możliwości znajdującej się w jaskrawej opozycji względem stosownej kompetencji sądu realizowanej w sytuacjach wyjątkowych i przy spełnieniu ustawowo zakreślonych warunków. $\mathrm{W}$ zarysowanym kontekście twierdzenie o braku odpowiedniego zakazu dowodowego nie jest przekonujące, skoro dopasowanie tej tezy do rzeczywistości karnoprocesowej spowodowałoby konsekwencje daleko odbiegające od modelu zracjonalizowanego działania.

Należy wreszcie zaakcentować, że naruszenie tajemnicy dziennikarskiej przez osobę zobowiązaną do jej strzeżenia stanowi przestępstwo ${ }^{26}$. Fakt ten

z obowiązku dochowania tajemnicy zawodowej przez jej depozytariusza w rozumieniu art. 180 § 2 k.p.k. opowiedział się P. K. Sowiński, Prawo świadka..., s. 156. Przeciwne stanowisko, w aspekcie tajemnicy dziennikarskiej, zdaje się wyrażać E. Ferenc-Szydełko, op. cit., s. 139-140.

${ }^{23} \mathrm{Na}$ tę istotną okoliczność zwrócił już uwagę A. Bojańczyk, op. cit., s. 32 i 36.

${ }^{24}$ J. Sobczak, Prawo prasowe. Komentarz..., s. 642-646; idem, Tajemnica..., s. 400-403.

${ }^{25}$ A. Bojańczyk, op. cit., s. 38-39. Zob. także D. Szumiło-Kulczycka, op. cit., s. 128.

${ }^{26}$ Sporna jest natomiast kwestia, czy podstawę pociagnięcia do odpowiedzialności karnej stanowi w tym wypadku art. $266 \S 1$ k.k., czy art. 49 p.p. Na ten temat zob. np. A. Guzik, op. cit., s. 192-195. Por. 
dostrzegli adherenci stanowiska Sądu Najwyższego, wyrażając zarazem swa aprobatę dla przesłuchania przez sąd dziennikarza, który z własnej inicjatywy ujawnia wiadomości objęte tajemnicą i jednocześnie kłamliwie zaprzecza, iżby wiadomości odnoszące się do informatora były w tej tajemnicy zawarte ${ }^{27}$. Przyznać trzeba, że ta akceptacja na w swej istocie charakter kuriozalny, ponieważ zmierza do traktowania procesu karnego jako legitymizacji nieetycznego dziennikarstwa. Zresztą niezależnie od tego, w jakim stopniu sąd poweźmie podejrzenia co do rzeczywistego istnienia tej tajemnicy lub zadowoli się twierdzeniem dziennikarza o jej nieistnieniu -jest to pogląd sytuujacy organ sądowy w roli podmiotu niejako zatwierdzającego praktyki oparte na takich motywach postępowania, które z pewnością na aprobatę nie zasługują.

Przyjmując zatem niedopuszczalność samowolnego zwolnienia się dziennikarza z obowiązku zachowania wiążącej go tajemnicy, gdy osoba ta jest przesłuchiwana $\mathrm{w}$ charakterze świadka, należy zauważyć, że kwestia ta nie będzie już tak jednoznaczna w razie gdyby dziennikarz posiadał status oskarżonego. Zasadnicza odmienność pozycji prawnoprocesowej oskarżonego, determinowana prowadzeniem postępowania karnego przeciwko niemu i zagrożeniem karą kryminalną, uzasadnia skierowanie rozważań w stronę prawa do obrony. W analizowanej kwestii właściwy punkt odniesienia wyznacza uprawnienie oskarżonego do składania wyjaśnień, jako niezaprzeczalna forma realizacji prawa do bronienia się przed stawianymi zarzutami ${ }^{28}$.

Tak jak jednak nie sposób na płaszczyźnie in abstracto zakładać prymatu prawa do obrony nad obowiązkiem zachowania tajemnicy zawodowej, w tym dziennikarskiej ${ }^{29}$, tak niewskazane byłoby apriorycznie przyjmować możliwość poświęcenia przez dziennikarza w trakcie składania wyjaśnień jego tajemnicy zawodowej w każdym wypadku, w którym wedle jego uznania wymaga tego realizowanie prawa do obrony ${ }^{30}$. Dopuszczenie tej drugiej ewentualności byłoby równoznaczne $\mathrm{z}$ przyznaniem oskarżonemu nieograniczonej wręcz swobody w zakresie decydowania o ujawnieniu sekretu zawodowego, a tym samym oznaczałoby znaczące poszerzenie granic prawa do obrony do tego stopnia, że

nadto, E. Plebanek, M. Rusinek, Ujawnienie tajemnicy zawodowej w procesie karnym a odpowiedzialność karna, „Czasopismo Prawa Karnego i Nauk Penalnych” 2007, nr 1, s. 74-84.

${ }^{27}$ Tak J. Sobczak, który w rezultacie postuluje sformułowanie w k.p.k. bezwzględnego zakazu dowodowego uniemożliwiającego przesłuchanie dziennikarza w tego typu sytuacjach, idem, Prawo prasowe. Komentarz..., s. 646-647. Zob. także krytyczną ocenę przyjętej w art. 180 § 2 k.p.k. koncepcji niezależnego od woli świadka zakazu jego przesłuchania, dokonaną przez M. Rusinka, prowadząca - jak się wydaje - do zabezpieczenia interesu wymiaru sprawiedliwości ponad rozsądną miarę, ,za wszelką cenę" (idem, op. cit., s. 108-110).

${ }^{28}$ Co do znaczenia wyjaśnień oskarżonego zob. np. R. Kmiecik (red.), Prawo dowodowe. Zarys wykładu, Warszawa 2008, s. 146-148; K. Marszał, w: idem (red.), S. Stachowiak, K. Zgryzek, op. cit., s. $275-278$.

${ }^{29}$ Inaczej, choć z pewną dozą ostrożności: E. Plebanek, M. Rusinek, op. cit., s. 85-86.

${ }^{30}$ Zob. tezę wypowiedzianą na tle analogicznego problemu przez Sąd Najwyższy w stosunku do tajemnicy adwokackiej, uchwała SN z 29 listopada 1962 r., sygn. VI KO 61/62, OSN 1963, nr 7-8, poz. 157. Zdaniem SN, prawo do obrony nie może doznać ograniczenia przez związanie danej osoby obowiązkiem tajemnicy zawodowej, gdyż adwokat znalazłby się w gorszym położeniu niż każda inna osoba pozostająca w stanie oskarżenia. Tę tezę zdaje się aprobować bez zastrzeżeń P. K. Sowiński, Ujawnienie $w$ wyjaśnieniach oskarżonego okoliczności stanowiacych tajemnice chroniona prawem, w: Z. Ćwiąkalski, G. Artymiak (red.), op. cit., s. 453 i 457-458. Krytyczne stanowisko w tej kwestii zajęła D. Karczmarska, op. cit., s. 437. 
w określonych wypadkach wiązałoby się także z nadużyciem tego generalnego uprawnienia oskarżonego. Prawo do obrony musiałoby wtedy pełnić rolę swoistego antykontratypu uchylającego bezprawność wszelkich zachowań polegających na podaniu do wiadomości danych objętych tajemnicą. Bez znaczenia byłoby wtedy istnienie ewentualnych okoliczności usprawiedliwiających naruszenie tajemnicy dziennikarskiej lub ich brak. Obojętne byłoby także to, kogo problem samozwolnienia dotyczy, a w rezultacie nie brano by pod uwage wzajemnej niezależności w podleganiu odpowiedzialności karnej redaktora naczelnego i redaktora $\mathrm{z}$ tytułu posiadanego wpływu na publikację materiału prasowego oraz dziennikarza w aspekcie jego autorstwa.

Rozwiązaniem nieadekwatnym do rozważanej sytuacji może się okazać znana prawu karnemu koncepcja stanu wyższej konieczności ${ }^{31}$ (art. 26 k.k.). Fakt znalezienia się dziennikarza w sytuacji prawnej, w której - z jednej strony-grozi mu odpowiedzialność karna $\mathrm{z}$ tytułu zarzucanego mu przestępstwa w ramach prowadzonego procesu karnego, a $\mathrm{z}$ drugiej - naraża się on na kolejną sankcję karną $\mathrm{z}$ powodu ujawnienia informacji stanowiących tajemnicę zawodowa, nie tworzy wspólnego mianownika ze stanem wyższej konieczności ze względu na wymagany w tym wypadku warunek wystapienia niebezpieczeństwa (art. $26 \S 1$ k.k.). Nie można bowiem uznać za niebezpieczeństwo zachowań podjętych zgodnie $\mathrm{z}$ prawnym upoważnieniem ${ }^{32}$. Jak wiadomo, w razie istnienia stosownej podstawy faktycznej związanej z popełnieniem przestępstwa przez dziennikarza oraz $\mathrm{w}$ razie spełnienia ogólnego wymogu dopuszczalności procesu karnego odpowiednie organy wszczynaja i prowadzą przeciwko dziennikarzowi postępowanie w granicach nakazu prawnego.

Prawdopodobnie optymalnym rozwiązaniem jawi się wyodrębnienie osobnego kontratypu ${ }^{33}$, który $\mathrm{w}$ swej istocie $\mathrm{w}$ pewnym zakresie może przypominać stan wyższej konieczności, ale nie będzie łączyć się ze ziszczeniem się warunku wystąpienia bezprawnego niebezpieczeństwa. Musi być więc z pewnościa zachowany wymóg subsydiarności, sprowadzający się w omawianym wypadku do tego, że poświęcenie tajemnicy dziennikarskiej jest jedynym skutecznym sposobem obrony przed skazaniem za zarzucane przestępstwo $^{34}$. Nie trzeba szeroko dowodzić, że ocena zachowania oskarżonego $\mathrm{w}$ istotny sposób będzie uzależniona od wyniku konfrontacji skonfliktowanych dóbr. To zestawienie powinno z kolei uwzględniać konkretne uwarunkowania danej sprawy. W szczególności trzeba mieć na uwadze porównanie ciężaru gatunkowego obu czynów $\mathrm{z}$ odniesieniem do występujących okoliczności faktycznych, a zwłaszcza należy dokonać analizy zakresu ujemnych następstw wywołanych ujawnieniem tajemnicy dziennikarskiej oraz oszacować charakter korzyści uzyskiwanych przez oskarżonego z tytułu grożącej mu odpowiedzialności karnej w toku prowadzonego przeciwko niemu procesu.

${ }^{31}$ Odmiennie: D. Karczmarska, op. cit., s. 435-437 i 438; R. A. Stefański z powołaniem się na poglądy doktryny, idem, op. cit., s. 124; D. Szumiło-Kulczycka, op. cit., s. 125; J. Sobczak, Tajemnica..., s. 408.

${ }^{32}$ A. Zoll, w: K. Buchała, A. Zoll (red.), Kodeks karny. Część ogólna. Komentarz do art. 1-116, Kraków 2000, s. 236; L. Gardocki, Prawo karne, Warszawa 2000, s. 116.

${ }^{33}$ Tak również E. Plebanek i M. Rusinek, op. cit., s. 87-88.

${ }^{34}$ Por. Z. Gostyński, Glosa..., s. 110. 
W świetle przeprowadzonych rozważań widać wyraźnie, że wyznaczenie modelowych granic respektowania tajemnicy dziennikarskiej $\mathrm{w}$ obszarze karnoprocesowym jest wypadkową uwzględnienia rozmaitych racji i okoliczności, także tych wykraczających poza postępowanie karne. W każdym razie wywody zamykające się w niniejszym opracowaniu stanowiły próbę wskazania takich rozwiązań, które w pełni odpowiadałyby konotacji wyrazu „kompromisowość", w następstwie należytego oszacowania kolidujących wartości oraz właściwego ulokowania tajemnicy dziennikarskiej w systemie prawnym i społecznym.

dr hab. Radostaw Koper

Uniwersytet Slaski w Katowicach

\title{
LIMITS OF PROTECTION OF JOURNALIST SECRECY IN CRIMINAL PROCEEDINGS
}

\begin{abstract}
Summary
The paper is an attempt to delineate model boundaries of protection of journalist secrecy when it comes to criminal proceedings. Despite the existing protection available under media law which also affects the criminal trial, certain modifications are still necessary. The paper discuses events when a journalist must be released from the duty of secrecy in the course of criminal proceedings. The existing normative regulations have been analysed, their defects identified, and certain improvements and amendments proposed. The controversial issue of the actual waiver of journalist secrecy has also been examined. The general goal of the paper is to postulate creation of solutions that will result from proper decisions made when the concurrent interests and values clash.
\end{abstract}

